\title{
GOOD SCHOOL GOVERNANCE IMPLEMENTATION THROUGH THE ESTABLISHMENT OF INTERNAL CONTROL UNIT
}

\author{
Maulana Rizky, Sri Setiti, Monry Fraick Nicky Gillian Ratumbuysang \\ maulanarizky.sofyan@gmail.com
}

\author{
ARTICLE INFORMATION \\ Article history: \\ Received July 28, 2016 \\ Revised Nov 04, 2017 \\ Accepted Dec 09, 2017 \\ JEL Classifications \\ I28; M42

\section{Key Words:} \\ Fraud; \\ Internal Control Unit; \\ School

\section{DOI:} \\ 10.21532/apfj.001.17.02.02.08
}

\begin{abstract}
This article describes the phenomenon of fraud occurring due to weak internal control system. Based on a study conducted by the Association of Certified Fraud Examiners (ACFE), one of the major causes of fraud is lack of internal control, or $29 \%$, and override of existing internal control, or 20\%. (ACFE, 2016). The phenomenon of fraud is still very common in Indonesia. Poor organizational governance is also part of the major causes of fraud. Corruption in Indonesia has spread to all sectors, including the education sector. There are many cases of corruption occurring in schools involving principals, treasurers, and teachers. The world of education in Indonesia is severely tarnished by the involvement of teachers in several cases of fraud. If this continues, the world of education will no longer be a role model. Improved organizational governance is necessary for early detection of fraud. This is intended to save Indonesia, especially education sector. The establishment of Internal Control Unit in schools is crucial because the Internal Control Unit serves not only as the implementation of good school governance but also as a tool to prevent fraud at schools.
\end{abstract}

\section{INTRODUCTION}

The problem of corruption occurring in the world, especially in Indonesia, always becomes a hot topic to discuss. Corruption seems to be a culture. When viewed more deeply, corruption occurs in all levels of life, from ordinary people to officials and from the private sector to the public sector. Corruption can no longer be classified as ordinary crime, but an extraordinary crime because it has systemic impact that may threaten the life of the nation. Indonesia Corruption Watch states that the state loss due to corruption in 2015 was as much as IDR 3.1 trillion.

Indonesia is still categorized as a developing country. The characteristic of a developing country is on 
high level of corruption. One of the causes is that the developing countries still have no good institutional system and good governance system. Corruption has a huge impact on all aspects. Besides being able to damage the economy, it can also destroy the life of nation and state. Kofi Anan, former UN Secretary General described "Corruption is like a contagious disease creeping slowly but deadly, creating widespread destruction in society. Corruption undermines democracy and rule of law, promotes violations of human rights, distorts the economy, degrades the quality of life, and allows criminal organizations, terrorism and various threats to security to flourish "(UN, 2004)

Indonesia Corruption Watch (ICW) states that in 2015 there were 5 sectors that contributed to corruption cases in Indonesia. The five sectors were the regional financial sector, education sector, transportation sector, social sector, and health sector. Based on the research done by ICW, the education sector was ranked two. This rank is not a good achievement but a very disappointing achievement.

State losses occurring in education sector for a decade, based on ICW's monitoring, were IDR 1.3 trillion. The posts that become an easy target for corruption in are Special Allocation Fund (better known in Indonesia as DAK) and School Operational Assistance (better known as BOS). The Government of Indonesia has made the education sector a top priority to be promoted, as stated in the 1945 Constitution of 4th amendment Article 31 Paragraph 4,
"The State prioritizes education budget at least twenty percent of the state budget and regional budget to meet the needs of national education". The Government of Indonesia's good intention to advance the education sector by providing a very large allocation of funds, in fact, provides not only positive effect but also negative effect. The management of funds in the education sector has not been optimally implemented resulting in gaps for corruption.

A report released by the World Bank through the "Education Public Expenditure Review" Report states that the Indonesia's education function budget of $20 \%$ of the State Budget has not been effective in improving the quality of education. One of the causes is the fund management that has not been optimal so as to make it vulnerable to be corrupted.

Corruption in the education sector is not shocking news, because it has been going on for a decade. It is a very embarrassing, very sad, and very disappointing thing. According to the Education Fund Monitoring Report 2014 conducted by Deputy of Prevention of Indonesian Corruption Eradication Commission (better known in Indonesia as KPK), the problems occurring in the management of education budget are caused by four factors: weak internal control, weak administrative system, supervision vacuum, and weak public / social control. These are what cause the education fund / budget is vulnerable to be abused.

The corruption actors in education sector can be divided into four:

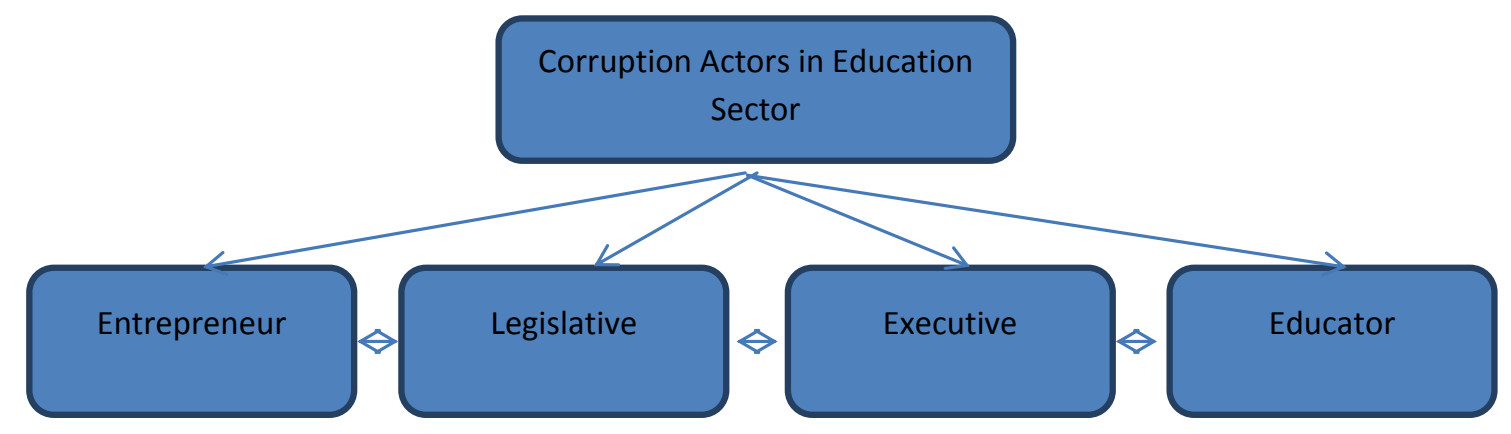


The author deliberately divides the corruption actors in education sector in order to make it easier to focus on the topic of this paper. The education budget sourced from the State Budget and Regional Budget is usually formulated by the executive through the program / activity and then authorized by the legislative through budgeting in the State Budget / Regional Budget. If the program is in the form of procurement of goods and services, the role is handled by the entrepreneur, and then the goods / services are used by executives and educators. Here are the roles of corruption actors in the education sector:

1. Executive (Education Office, Ministry of Education and Culture) formulates programs and activities, such as procurement of goods / services, and then submits the proposals to the legislatives. After approval, there will be auction of procurement of goods and services. Corruption is usually committed by winning one party / partner or marking up the value.

2. Legislative performs budgeting and ratification of education budget related to the executive's proposal (Education Office, Ministry of Education and Culture). If the budget is approved, the executive will then execute the budget. For example, if the procurement of goods and services must be conducted through an auction, the fraud committed is usually in the form of bribery to smoothen the program executed by the executive.

3. The entrepreneurs who win the auction of procurement of goods and services usually commit corruption by providing goods and services that do not meet the technical specifications.

4. Educators (principals, teachers, lecturers) send proposals to the executive regarding the program to be run, for example the BOS Fund program. In this case, the educators commit corruption by making irregularities in the use of BOS Funds.

The fraud / corruption in education sector not only damage state economy, but also destroy the moral of the nation. The author of this study focuses on the corruption committed by the school (principals and teachers). Corruption occurring in the school environment can cause the education of Indonesia to lose confidence and give bad example for the people of Indonesia. School should be a role model for other sectors, but in fact many acts of corruption even happen in school.

Unfortunately, some cases of corruption occurring in schools have involved many principals and teachers. The author sees that corruption is caused by two factors. The first factor is the ignorance of the prevailing regulations and the second factor is the factor of intent (moral). The factor of ignorance that leads to corruption is caused by the low understanding of the prevailing regulations and the absence of internal controls. This can make erroneous actions continue to occur. Meanwhile, the factor of intent is associated with the moral of the perpetrators of corruption.

The author assess that bad school governance can lead to potential fraud / corruption, caused by both ignorance and intent factors. So, the author is interested in raising topic related to good school governance to prevent the occurrence of fraud in schools.

\section{DISCUSSION}

Association of Certified Fraud Examiners (ACFE) menggambarkan fraud yang terjadi dalam hubungan kerja (Occupational Fraud) secara skematis melalui fraud tree/ pohon kecurangan. Pohon kecurangan/fraud tree disajikan pada bagan 2 .

The Association of Certified Fraud Examiners (ACFE) describes the occupational fraud schematically through the fraud tree, as presented in Chart 2. 


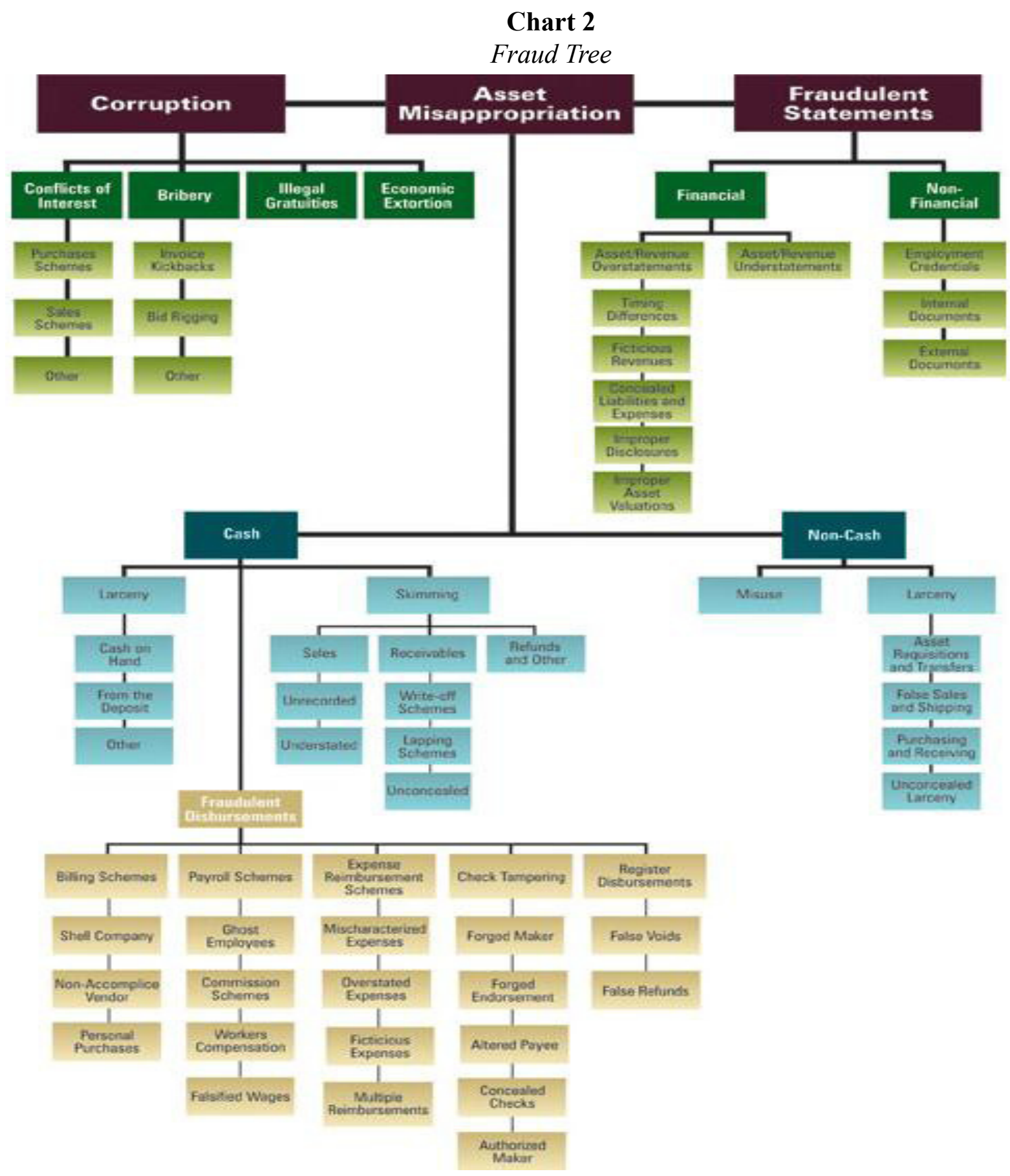

Source: Association of Certified Fraud Examiners, 2008 Report to the Nation on Occupational Fraud and Abuse.

Based on the above chart, it can be seen that occupational fraud has three main branches, namely corruption, asset misapproption, and fraudelent statements. Chart 3 describes the ACFE report that the three major causes of corruption, asset misapproption, and fraudelent statements are: 


\section{Chart 3}

3 Biggest Weakness Factors that cause Fraud

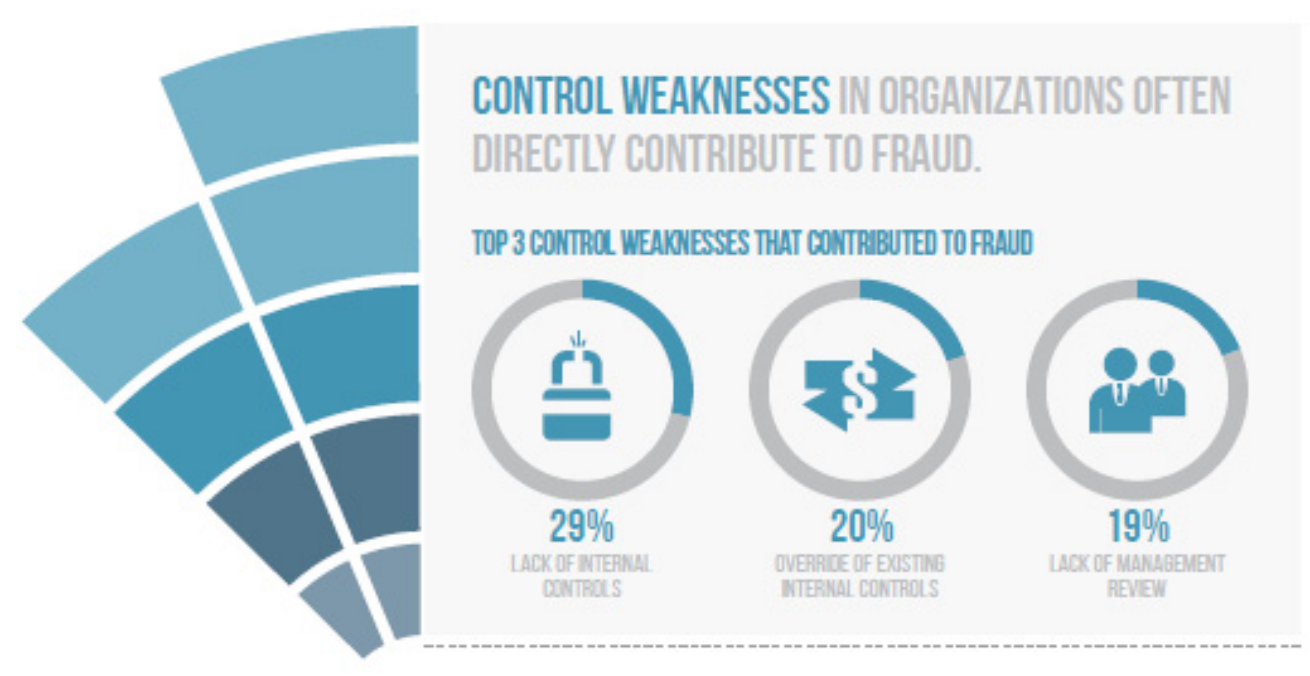

Source: Association of Certified of Examiners, 2016 Report To the Nation on Occupational Fraud and Abuse.

Factor of lack of internal controls contributes $29 \%$, override of existing internal controls contributes $20 \%$, and the lack of management review contributes $19 \%$. Based on the above chart, it can be seen that when internal control is ruled out or even does not exist, the fraud will occur.

The author sees the fraud phenomenon occurring in the education sector, especially in schools, because there is no work unit that specially handles internal supervision / control, so that fraud often occurs in the school environment. This is in accordance with the report of ACFE that lack of internal control can be the major cause of the occurrence of fraud. Even when an organization has internal controls, fraud may still occur. This is in accordance with a report of ACFE which states that the override of existing internal control is ranked second to fraud.

The establishment of the Internal Control Unit in schools is a must. Besides helping schools achieve the goals of school organizations and educational organizations, Internal Control Unit also helps save the state's finances. The establishment of the Internal Control Unit in schools is one step towards good school governance. When the school governance is bad, the organization is easily porous due to adverse actions, one of which is fraud. The Internal Control Unit applied in schools will, of course, have different characteristics from the Internal Control Unit applied in companies, because it must be in accordance with the needs of the entity concerned

The school's Internal Control Unit can carry out accounting control and administrative control. Accounting control can be done such as by maintaining school assets and preventing inefficiency in schools. Administrative control can be done so that every step / action of the school in the use of state money is in accordance with the rules and legislation in force. Although organizationally, schools are under the auspices of the education office and BPKP (Financial and Development Supervisory Agency) as the government partner in terms of internal auditors, the author sees that it does not work optimally because the coverage of supervision conducted 
by BPKP is too wide, thus enabling fraud to occur in some places. The establishment of Internal Control Unit in schools can be more effective in preventing fraud in schools.
The author is trying to make a scheme for the position of the Internal Control Unit in schools as seen in Chart 4 below.

\section{Chart 4}

Development of School Organization Structure with the Establishment of Internal Control Unit

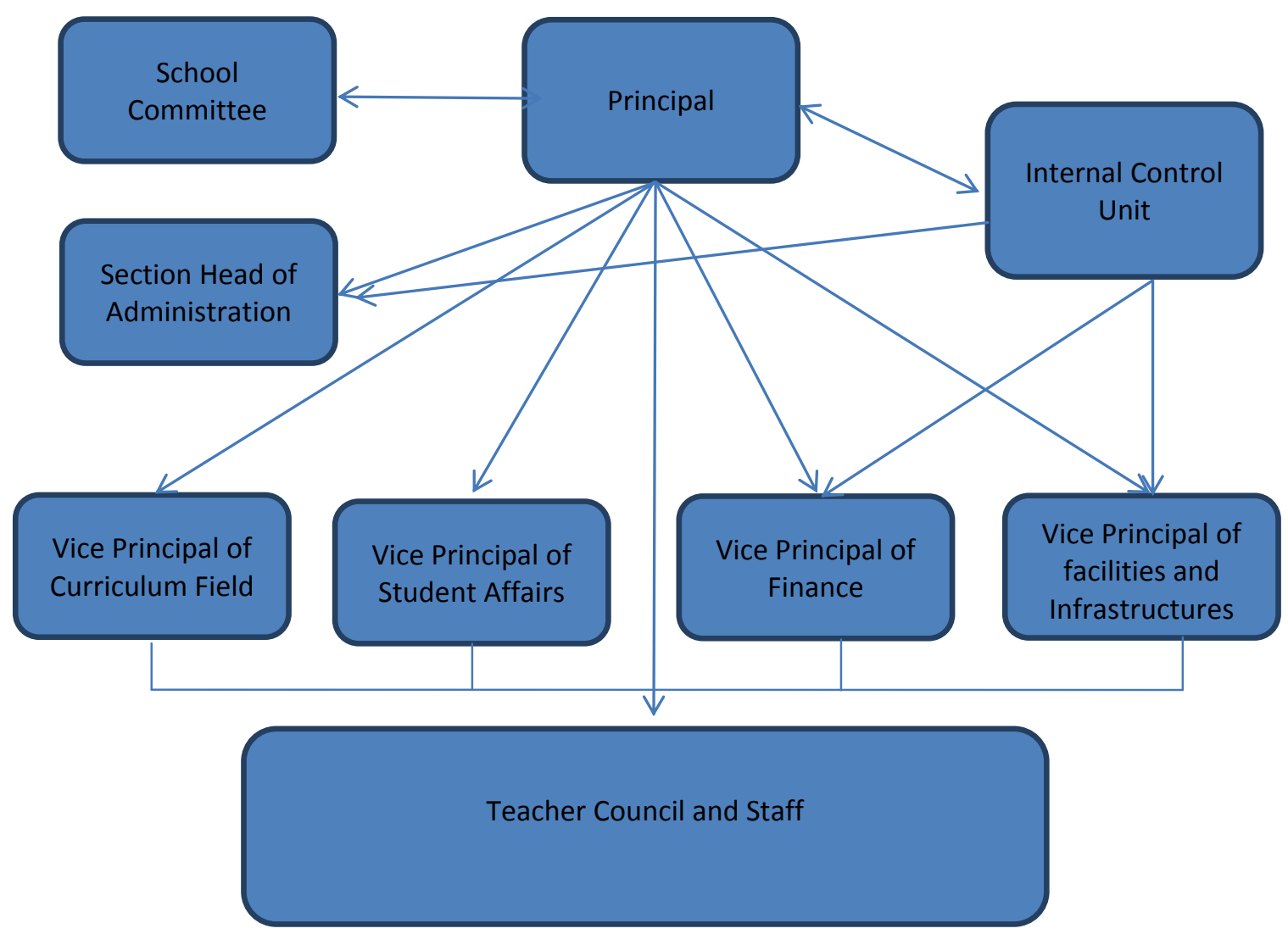

The above chart illustrates organizational structure in schools with the establishment of School Internal Control Unit. The following is the description of the Internal Control Unit in schools.

\section{- Human Resources (HR)}

o The Human Resources serving in the Internal Control Unit must have skills, especially in finance and accounting.

o The Human Resources serving in the Internal Control Unit are selected by the school committee, principal, and teacher council.
- Internal Control Unit Workflow

o The Internal Control Unit is responsible to the principal

o The Internal Control Unit serves as_supervisor of non-academic affairs such as Administration, Finance, and Facilities and Infrastructures sections. This is a major objective because one of the objectives of the establishment of the Internal Control Unit is to secure school assets and to help schools detect deviation and non-compliance with laws and regulations 
relating to the use of BOS funds, Education Aid Funds, Use of Grants earlier.

\section{CONCLUSON}

Based on the above explanation, the author assess that the establishment of Internal Control Unit (SPI) in schools is one of the realization of Good School Governance (GSG) and is considered capable of preventing the occurrence of fraud. The limitation of this paper is on how effective and efficient the establishment of Internal Control Unit to prevent fraud in schools. Hopefully, this idea could be acted upon by related parties regarding fraud prevention in schools with the establishment of Internal Control Unit in schools in order to realize Good School Governance (GSG)

\section{REFERENCES}

Arrens, A. et al. 2006. Auditing dan Jasa Assurance (Pendedekatan terintegrasi). Edisi 12. Jakarta: Airlangga.

Association of Certified Fraud and Examiners. Global Fraud Study. 2008 Editon

Association of Certified Fraud and Examiners. Global Fraud Study. 2016 Editon

Hery. 2016. Auditing dan assurance. Jakarta:

Grasindo

Paparan Monitoring \& Evaluasi Sektor Pendidikan, Deputi Pencegahan KPK. 2014

Tuannakotta, Theodorus M. 2010. Akuntansi Forensik \& Audit Investigatif. Edisi 2. Jakarta: Salemba Empat.

United Nations Convention Against Corruption. 2004.
World Bank. 2013. Education Public Sector Expenditure Review

http://www.antikorupsi.org/id/content/ kerugian-negara-dari-korupsi-sektorpendidikan-capai-13-triliun-rupiah

http://acch.kpk.go.id/tema/-/blogs/potensikorupsi-dunia-pendidikan 
Maulana Rizky, Sri Setiti, Monry Fraick Nicky Gillian Ratumbuysang : Good school government.....

Page 203-209

\section{Asia Pasific Fraud Journal}

Volume 2, No.2 ${ }^{\text {nd }}$ Edition (July-December 2017) 